\title{
Correction to: Consumer (Co-)Ownership in Renewables in California (USA)
}

Felicia van Tulder, Sharon Klein, and Erika Morgan

\section{Correction to:}

Chapter 21 in: J. Lowitzsch (ed.), Energy Transition, https://doi. org/10.1007/978-3-319-93518-8_21

The original chapter was inadvertently published with incorrect affiliation of one of the authors 'E. Morgan'. The affiliation has been corrected in the chapter as below:

E. Morgan

California Alliance for Community Energy, San Diego, CA, USA

Changed to:

E. Morgan

Energetic Management Associates, San Diego, CA, USA 